\section{International Scientific Journal Theoretical \& Applied Science}

p-ISSN: 2308-4944 (print)

e-ISSN: 2409-0085 (online)

Year: 2014

Issue: 11

Volume: 19

Published: 30.11 .2014

http://www.T-Science.org

SECTION 31. Economic research, finance, innovation, risk management.

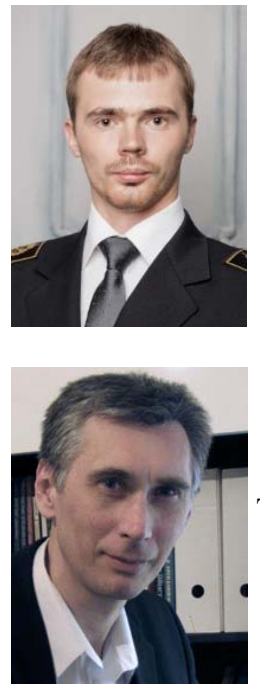

Dmitry Aleksandrovich Lalomov

Postgraduate

The National University of Mineral

Resources (Mining University),

St. Petersburg, Russia

lalomov@yahoo.com

Gennady Vasilyevich Kovalenko

Associate professor, Ph.D.,

The St. Petersburg State Politechnic

University,

St. Petersburg, Russia

7525268@gmail.com

\title{
USING THE RISKYPROJECT SOFTWARE WHEN CALCULATING THE RISK APPROACH BASED COST EFFECTIVENESS OF ENGINEERING-GEOPHYSICAL WORKS
}

\footnotetext{
Abstract: Engineering geophysics is a science focused on studying geological environment surrounding engineering constructions. In some cases, results of engineering surveys are of a probabilistic nature and can hardly be economically evaluated using standard procedures. Intaver Institute has created an algorithm of evaluating project risks' impact in their RiskyProject software. This algorithm enables us to evaluate cost effectiveness of engineering surveys using the risk approach.

Key words: Engineering geophysics; cost effectiveness; quantitative risk analysis; risk management; engineering survey; design; construction; risk-based approach.

Language: English.

Citation: Lalomov DA, Kovalenko GV (2014) USING THE RISKYPROJECT SOFTWARE WHEN CALCULATING THE RISK APPROACH BASED COST EFFECTIVENESS OF ENGINEERINGGEOPHYSICAL WORKS. ISJ Theoretical \& Applied Science 11 (19): 16-19. doi: http://dx.doi.org/10.15863/TAS.2014.11.19.4
}

\section{Introduction}

Uncertainty abounds in today's economy. Every organization is, to some extent, in the business of risk management, no matter what its products or services [2]. Engineering surveys are no exception. There are universal risk management advices [1]. But they are general in nature and require significant adaptation to each specific situation.

In most cases engineering surveys and geophysics are thought of only when settlement of fill takes pace at the site or piles start ether sinking or getting stuck not reaching their target depth [10] (Fig. 1). So what will be the duration of an investment and construction project if risks determined by the geological environment start unfolding? Perhaps the most striking evidence of such a situation is the washout in the St. Petersburg Metro between Lesnaya and Ploschad Muzhestva stations. The accident in that section was caused by a soil flow damaging the tunnel constructions. Due to a critical subsidence, the main line tunnels had to be closed and flooded. Passenger service in this section was closed from December 2, 1995 till June 26, 2004 - until new bypass tunnels were built and commissioned. Thus, insufficient information of the soil profile of that site increased the project duration by nine years.

The key issue here is the following: to which extent the exploration degree of site geological structure can influence the duration and cost of planned construction works based on data obtained in the course of engineering surveys [3]? The evaluation of geophysical surveys' influence on the total cost and duration of an investment and construction project will result in a decision on the viability of such surveys.

When solving the issue of the viability of engineering surveys, particularly geophysical surveys, the problem of evaluating their cost effectiveness ratio arises [8]. The absence of any correct method of performing such evaluation is one of the constraints for further development of geophysical surveys in the investment and construction practice. 

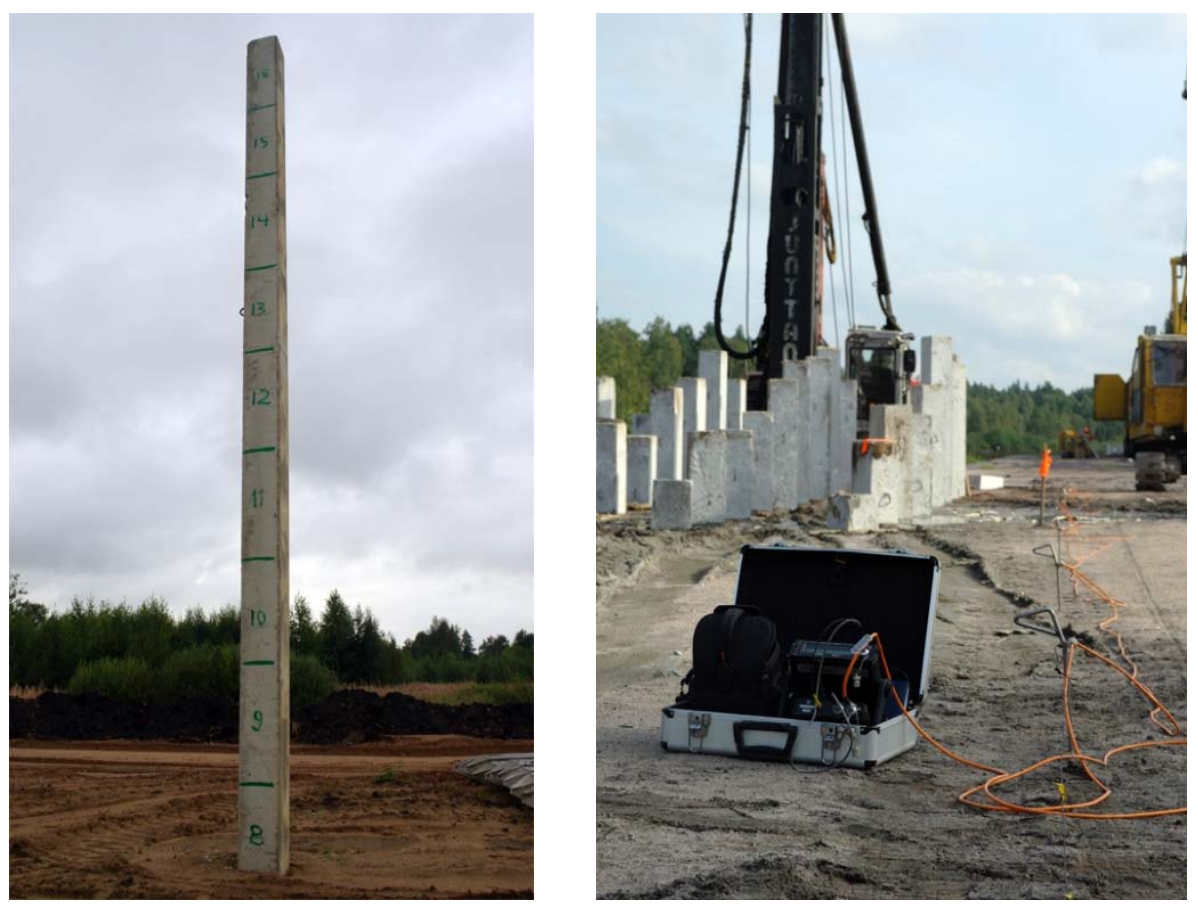

Figure 1 - The pile stucks not reaching target depth.

\section{Study Process}

The study was aimed at evaluating the cost effectiveness of engineering works. The risk approach was suggested as a methodological basis for a correct evaluation $[5,6]$. The idea was to compare the periods of construction project duration involving and not involving geophysical methods under the impact of risks typical of engineering surveys.

The suggested approach involves using engineering surveys in an investment and construction project as measures of handling the risks of such project, that enabling companies to use standardized methods of quantitative risk analysis [4].

The RiskyProject Professional 5.0 software [9], based on logical-and-probabilistic modeling employing the Monte Carlo method [7], was used as an instrument for risk calculations.

The cost effectiveness of using geophysical surveys can be calculated the following way:

$$
\ni_{\ni \phi}=\frac{\left(T_{2}-T_{1}\right) \cdot P_{c / c}}{P_{\mathrm{r} \phi}}
$$

where:

- $\ni_{э \phi}$ is the cost effectiveness of using geophysical surveys;
- $T_{1}$ is the project duration using geophysical methods;

- $T_{2}$ is the project duration without using geophysical methods;

- $P_{c / c}$ is the daily average cost of the project;

- $P_{\mathrm{r} \phi}$ is the cost of geophysical surveys.

This calculus is an adequate portrayal of real cost effectiveness of geophysical surveys.

The problem of using Formula (1) is that it is necessary to have statistically significant evaluations of $T_{1}$ and $T_{2}$ as well as $P_{c / c}$ to make such a calculation. Under the absence of high-quality competition, the participants of the investment and construction market are not interested in any collection and publication of statistically reliable data concerning construction failures connected with cost overrun and disruption of commissioning deadlines. Taking that into account, the authors had to use the expert evaluation method for risk identification and evaluation. The key idea here is to compare the weaknesses of tunneling and drilling works to the strengths of geophysical surveys. As the risks the relative weaknesses of tunneling and drilling works are chosen that can be compensated due to the use of the relative strengths of geophysical surveys (see Table 1). 
Table 1

Measuring project risks due to the use (increase of the extent) of geophysical surveys in the total amount of engineering surveys

\begin{tabular}{|c|c|c|c|c|c|c|}
\hline \multirow{2}{*}{\multicolumn{2}{|c|}{$\begin{array}{c}\text { Risks } \\
\text { of engineering surveys }\end{array}$}} & \multirow{3}{*}{$\begin{array}{c}\begin{array}{c}\text { Weaknesses } \\
\text { of tunneling and } \\
\text { drilling works }\end{array} \\
\text { Relatively high cost }\end{array}$} & \multirow{3}{*}{$\begin{array}{c}\begin{array}{c}\text { Strengths of } \\
\text { geophysical surveys }\end{array} \\
\text { Relatively low cost }\end{array}$} & \multicolumn{2}{|c|}{$\begin{array}{c}\text { Probability of risk } \\
\text { occurrence }\end{array}$} & \multirow{3}{*}{$\begin{array}{c}\begin{array}{c}\text { Risk } \\
\text { impact on } \\
\text { project } \\
\text { duration }\end{array} \\
30 \%\end{array}$} \\
\hline & & & & \multirow{2}{*}{$\begin{array}{c}\begin{array}{c}\text { Before } \\
\text { risk } \\
\text { reduction }\end{array} \\
30 \%\end{array}$} & \multirow{2}{*}{$\begin{array}{c}\begin{array}{c}\text { After } \\
\text { risk } \\
\text { reduction }\end{array} \\
15 \%\end{array}$} & \\
\hline 1 & Cost overrun & & & & & \\
\hline 2 & $\begin{array}{l}\text { Overrun project } \\
\text { deadlines (technical } \\
\text { aspect) }\end{array}$ & $\begin{array}{ll}\text { High } & \text { labor } \\
\text { coefficient }\end{array}$ & $\begin{array}{l}\text { High speed of } \\
\text { obtaining } \\
\text { Mobility }\end{array}$ & $30 \%$ & $15 \%$ & $30 \%$ \\
\hline 3 & $\begin{array}{l}\text { Overrun project } \\
\text { deadlines } \\
\text { (organizational } \\
\text { aspect) }\end{array}$ & $\begin{array}{l}\text { Need of approvals } \\
\text { and permits }\end{array}$ & $\begin{array}{l}\text { Nondestructive } \\
\text { remote sensing } \\
\text { survey }\end{array}$ & $20 \%$ & $10 \%$ & $30 \%$ \\
\hline 4 & $\begin{array}{l}\text { Insufficient } \\
\text { information }\end{array}$ & $\begin{array}{l}\text { Individual character } \\
\text { of surveys }\end{array}$ & $\begin{array}{l}\text { Bulk index of rocks } \\
\text { Continuous tracking } \\
\text { of borders }\end{array}$ & $20 \%$ & $10 \%$ & $\begin{array}{c}\text { resumption } \\
\text { of works } \\
\text { under the } \\
\text { project }\end{array}$ \\
\hline 5 & $\begin{array}{ll}\text { Absence } & \text { of } \\
\text { opportunity } & \text { to } \\
\text { conduct surveys } & \end{array}$ & $\begin{array}{l}\text { Bulky equipment. } \\
\text { Unacceptable harm } \\
\text { to the environment }\end{array}$ & $\begin{array}{ll}\text { Compact } & \text { equipment. } \\
\text { Nondestructive } \\
\text { remote } \quad \text { sensing } \\
\text { survey }\end{array}$ & $20 \%$ & $10 \%$ & $30 \%$ \\
\hline 6 & $\begin{array}{l}\text { Absence of the } \\
\text { opportunity } \\
\text { control results }\end{array}$ & $\begin{array}{l}\text { Possible errors in } \\
\text { the documentation. } \\
\text { Impossibility of } \\
\text { repeated } \\
\text { measurements }\end{array}$ & $\begin{array}{l}\text { Comprehensive } \\
\text { approach. Monitoring } \\
\text { opportunity. }\end{array}$ & $20 \%$ & $10 \%$ & $30 \%$ \\
\hline
\end{tabular}

Each of the weaknesses is accompanied by a certain risk typical of the survey stage. Some risks have a general (global, according to the Intaver Institute terminology) character, e.g. the "insufficient information" risk that exercises the greatest influence on the design stage. The "absence of the opportunity to control results" risk is also a global one since it can result in design documentation errors and influence the construction stage progress.

To perform quantitative calculations, the abovementioned risks were "applied" to a model project consisting of three stages: surveys - design construction. The following values were adopted: the surveys stage duration - 4 days (minimum), 5 days (average) and 6 days (maximum) - depending on the risk occurrence probability and their treatment efficiency. The duration of the design and construction stages is 3 and 7 days respectively. The list of risks exercising influence on the model project are given in Table 1.

Risk occurrence probability and the extent of their influence on the model project were evaluated by experts.
The fact and power of influence of using geophysical surveys on the project in general were measured by comparison of the project duration without using geophysical methods to the project duration with using geophysical methods.

\section{Results}

The RiskyProject Professional package enabled the authors to make two independent calculi of the periods of the model project duration in general, with and without using geophysical methods. The calculation results are given in Table 2.

The data given in Table 2 shows that the probable model project duration with using geophysical methods can be increased by 1.23 days under the total project duration of 18 days, that making up about 7\%. By knowing the daily average cost of such a project and the cost of geophysical surveys, one can use Formula (1) to calculate the cost effectiveness of using geophysical methods. 
Comparison of the periods of probable project duration

Table 2

\begin{tabular}{|c|c|c|c|}
\hline \multirow{2}{*}{ Name } & \multicolumn{3}{|c|}{ Duration, [days] } \\
\cline { 2 - 4 } & $\begin{array}{c}\text { Without using } \\
\text { geophysical method }\end{array}$ & $\begin{array}{c}\text { With using geophysical } \\
\text { method }\end{array}$ & $\Delta$ \\
\hline Model project & 19.52 & 18.29 & 1.23 \\
\hline
\end{tabular}

\section{Conclusion}

The risk approach was suggested and used as an instrument of evaluating the cost effectiveness of geophysical surveys. The idea is to identify the risk list of an investment and construction project whose impact can be reduced by using geophysical methods, to evaluate the probability and extent of such impact for the variant with and without using geophysical methods as well as to make probability calculation of the project duration for each of the variants suggested. The geophysical methods in this case are considered along with the engineering methods instead of being compared to them. By comparison of the results obtained, conclusions of the viability and cost effectiveness of using geophysical surveys are made.

Thus, the suggested approach includes a comprehensive evaluation of the effectiveness and can be used under conditions of uncertainty, when the viability of using geophysical surveys cannot be explicitly estimated.

The risk approach enabled us to calculate the duration periods of the projects with due consideration of risk influence. The results of such calculation enable us to make valid conclusions concerning the use of certain geophysical methods and speak of their viability.

\section{References:}

1. (2000) A Guide to the Project Management Body of Knowledge - 2000 Edition. Philadelphia (USA): Project Management Institute.

2. Barton T, Shenkir W, Walker P (2002) Making Enterprise Risk Management Pay Off: How Leading Companies Implement Risk Managemen. Financial Times Prentice Hall: 265.

3. Japitana JN, Cataldo RM (2009) Geophysics for fun and profit: how to manage your due diligence risk. Proceedings of the Annual International Conference on Soils, Sediments, Water and Energy. V. 14. Article 26.

4. Kovalenko GV (2011) Risk management in innovations. St. Petersburg: SPbGPU: 143.

5. Lalomov DA, Kovalenko GV (2013) Cost Effectiveness Calculation of Engineering Geophysical Works Using Risk-Based Approach. Inzhenernye Izyskaniya (Engineering Surveys). No.1. pp. 36-40.
6. Lalomov DA, Kovalenko GV (2013) On the economic efficiency limits of geophysical survey application for trenchless laying of service lines. Inzhenernye Izyskaniya (Engineering Surveys). No.13. pp. 18-25.

7. Metropolis N, Ulam S (1949) The Monte Carlo method. Journal of the American Statistical Association. V. 44. No.247. pp. 335-341.

8. Reynolds JM (2011) An introduction to applied and environmental geophysics. UK: GeoSciences Ltd.: 712.

9. (2013) Risky project professional user guide. Calgary, Canada: Intaver Institute: 198.

10. Savin VA, Artugin AI, Lalomov DA (2012) Constructing a 3D engineering-geological environment model using georadiolocation data. Inzhenernye Izyskaniya (Engineering Surveys). No. 9. pp. 34-39. 